\title{
Quality of university libraries: the case of the Universidad de Granada
}

\section{Calidad de las bibliotecas universitarias: el caso de la Universidad de Granada}

\author{
ARJONA-JIMÉNEZ, José Antonio †' \& RUIZ-HERRERA, Noelia*” \\ 'Red de Bibliotecas Municipales de Granada, Spain. \\ "Universidad Internacional de la Rioja, Faculty of Health Sciences, Spain. \\ ID $1^{\text {st }}$ Author: José Antonio, Arjona-Jiménez. \\ ID $1^{\text {st }}$ Co-author: Noelia, Ruiz-Herrera / ORC ID: 0000-0001-6269-638X
}

DOI: $10.35429 / J T E R .2021 .19 .7 .28 .33$

Received January 25, 2021; Accepted June 30, 2021

\begin{abstract}
Objective: To present the analysis of the bibliographic collection of the Universidad de Granada (UGR) taking as a reference the teaching guides of the Degree in Psychology during the academic year 2019/2020. Method: An analysis of the bibliographic collection of the teaching guides of the Degree in Psychology of the UGR was carried out. Documents were analysed by title, year, document categorisation, document type and subject data. Information on availability and the possibility of consulting the document online was also included. The search was carried out in the automated online catalogue of the UGR Library. Results: A total of 1,775 bibliographic references were contained in the teaching guides of the 49 subjects (distributed among six departments). A total of $76.8 \%$ were considered complementary by the teachers and $89.2 \%$ of the proposed documents were books. The UGR libraries had $81.8 \%$ of the references, while the Psychology library had $65.8 \%$ of the material. $24.4 \%$ of the references had a more up-todate edition in the library. Contribution: The analysis of the bibliographic collection provides information on the adequacy of the teaching guides and the availability of the university library collection. This is an indicator of the quality of teaching and of the university library system.
\end{abstract}

University library, Psychology, Teaching guides

\section{Resumen}

Objetivos: Presentar el análisis del fondo bibliográfico de la Universidad de Granada (UGR) tomando como referencia las guías docentes del Grado de Psicología durante el curso 2019/2020. Metodología: Se realizó análisis del fondo bibliográfico de las guías docentes del Grado en Psicología de la UGR. Se analizaron los documentos por título, año, categorización del documento, tipo de documento y datos de la asignatura. También se incorporó información sobre disponibilidad y posibilidad de consultar el documento online. La búsqueda se realizó en el Catálogo automatizado disponible online de la Biblioteca de la UGR. Resultados: Un total de 1.775 referencias bibliográficas estaban contenidas en las guías docentes de las 49 asignaturas (distribuidas en seis departamentos). Un $76,8 \%$ eran consideradas complementarias por los docentes y un $89,2 \%$ de los documentos propuestos eran libros. Las bibliotecas de la UGR disponían del 81,8\% de las referencias, mientras que la biblioteca de Psicología tenía un $65,8 \%$ del material. Un $24,4 \%$ de las referencias tenían una edición más actualizada en la biblioteca. Contribución: Gracias al análisis del fondo bibliográfico se puede obtener información relativa a la adecuación de las guías docentes y a la disponibilidad de la colección de la biblioteca universitaria. Esto supone un indicador de calidad docente y del sistema bibliotecario universitario.

Biblioteca universitaria, Psicología, Guías docentes

Citation: ARJONA-JIMÉNEZ, José Antonio \& RUIZ-HERRERA, Noelia. Quality of university libraries: the case of the Universidad de Granada. Journal of Teaching and Educational Research. 2021. 7-19:28-33.

\footnotetext{
* Correspondence to the Author (Email: noelia.ruiz@unir.net)

$\dagger$ Researcher contributing as first author.
} 


\section{Introduction}

The adaptation to the European Higher Education Area (EHEA) in Spain resulted in a reorganization of the university context. To understand how the changes experienced have affected the system, various analyses of teaching and research quality have been carried out (Salajan, 2018). On the one hand, several studies have been carried out to determine the productivity of the different institutions (e.g., Buela-Casal, Guillén-Riquelme, Díaz-Román, Carneiro-Barrera, \& Quevedo-Blasco, 2019; Carneiro-Barrera, Díaz-Román, \& RuizHerrera, 2019), while on the other hand, the satisfaction of teachers and students with the implementation of the new system has been ascertained (v.gr. Escudero, 2019; Fernández, Arbulo, Muñoz, Agudo, \& García, 2017; López López, León Guerrero, \& Pérez García, 2018; Quevedo-Blasco, \& Buela-Casal, 2019; Núñez, Valdehita, \& Ramiro, 2018). In addition, there have been numerous studies based on the analysis of the components required to reorient professional practice in the new system (e.g., Álvarez-Rojo et al., 2011; Domingo-Coscolla, Bosco, Carrasco Segovia, \& Sánchez Valero, 2020; Mas-Torelló \& Olmos-Rueda, 2016; Saravia Gallardo, 2008). Beyond the evaluation of productivity or teaching quality, one way of analyzing the quality of the university system is through the services it offers, including the university library. According to the definition provided by Reitz (2004), a university library is a library established, maintained, and administered by a university to meet the information needs of its students and support its educational and research programs and other services. The Spanish University Libraries Network (REBIUN) is one of the institutions that promote the analysis of the quality of university libraries. It has been a sectoral committee of the Conference of Rectors of Spanish Universities (CRUE) since 1998 and all Spanish universities and scientific libraries are represented in it. Its mission is to lead, coordinate and give guidelines to university and scientific libraries, promoting cooperation and the implementation of projects to respond to the new challenges facing universities concerning learning, teaching, research, and lifelong learning (REBIUN, 1999).
One of its strategic lines of action is to improve the quality of these bodies by improving the catalog, drawing up guidelines and quality standards, reviewing publications, promoting training and professional development plans, and establishing mechanisms that make it possible to share experiences, projects, and good practices. The University of Granada (UGR), which consists of three campuses in the cities of Granada, Ceuta, and Melilla, has almost 53,000 members. The student body accounts for approximately $89 \%$ of the university community (UGR, 2020). According to the Shanghai Ranking, this institution is in the 201-300 positions globally and the 151-200 positions if only the subject of Psychology is considered. In addition, it stands out in the areas of Library and Information Science (36th place) (Shanghai Ranking Consultancy, 2019). This implies a high level of quality in the services offered to students. However, despite being one of the best public university teaching institutions in Spain (BuelaCasal et al., 2019), it does not have a system for analyzing the quality of its library collections. In this regard, in addition to the work carried out by REBIUN, there is a need to implement quality analysis protocols for these services, taking as a reference the bibliographies offered by lecturers in their subjects. The aim of this would be not only to continue to maintain quality standards in the bibliographic collections but also to ascertain indications of teaching quality. In other words, knowing the suitability of the bibliographies that teachers propose to students and their availability in the libraries not only provides indications of teaching quality but also of the quality of the services. While it has recently been concluded that collaboration (Pérez Marfil, 2021) and cooperation (Piedra \& Ponjuán, 2021) are basic for the development of complete and up-to-date training, the present study focuses on the concept of cooperation as a basis for the optimal composition of the library collection. Therefore, the objective of the present study was to analyze the bibliographic collection of the Degree in Psychology at the UGR. Specifically, the aim is to study two fundamental factors: 1) adequacy of the library collection concerning the teaching guides; 2) availability of the materials included in the teaching guides in the bibliographic collections. 


\section{Method}

To analyze the bibliographic collection of the UGR Library, the bibliographies recommended by the teaching staff in the guides for each subject of the entire Bachelor's Degree in Psychology were taken as a reference.

The search was carried out taking into account the following locations of the university libraries: Faculty of Psychology of the Granada Campus, other university libraries of Granada, Ceuta Campus, Melilla Campus, and the Electronic Library. Firstly, all the teaching guides for the course to be evaluated were compiled. (Retrieved from http://grados.ugr.es/psicologia/pages/infoacade mica/estudios\#_doku_guias_docentes). After that, the following data of the bibliographic citations provided by the teaching guide were stored: title, year, categorization of the document (basic, complementary, fundamental, general, textbook, e-book, compulsory and recommended), type of document (book, article or journal) and subject data. In addition, information relating to the search for the document in the catalog of the UGR Library was included, such as availability in any library of the UGR, date of the most recent document, the number of documents available in the library of the Faculty of Psychology, lendable copies at home from the library of the Faculty of Psychology and the existence of the possibility of consulting the document online. The search was carried out in the automated catalog available online in the UGR library (https://granatensis.ugr.es/discovery/search?vid =34CBUA_UGR:VU1\&lang=es\&mode=advan ced), selecting the advanced search option to be able to carry it out by specific fields. The search was carried out in the BUG Catalogue search profile when the document was a book and in Articles and more when it was an article. In this way, it was possible to narrow down by fields (e.g. author, title, subject, ISBN, ISSN, etc.) and to combine two fields simultaneously. In both cases, the search was done by Author/Creator and Title.

\section{Results}

The search allowed us to locate a total of 1,775 bibliographic references distributed over the four years of the degree program. Of these, one reference was eliminated from the list due to restricted access by the authors to the bibliographic data of the copy.
The range of publication years of the documents was from 1923 to $2019.87 .5 \%$ of the bibliography was before 2015 (the last five years) and 2011 was the year with the highest number of references.

Concerning the categorization of these documents, $76.8 \%$ of the bibliographies were considered complementary by the teachers. Some bibliographies were not specified at all (6.8\%) and the rest (16.4\%) were considered as Basic, Fundamental, General, Textbook, Ebooks, Compulsory, or Recommended. Of the six departments, Personality, Assessment, and Psychological Treatment accounted for $47.8 \%$ of the proposed bibliography. The department with the lowest percentage was Developmental and Educational Psychology (6.8\%). A summary of the availability of documents by the department can be found in Table 1 .

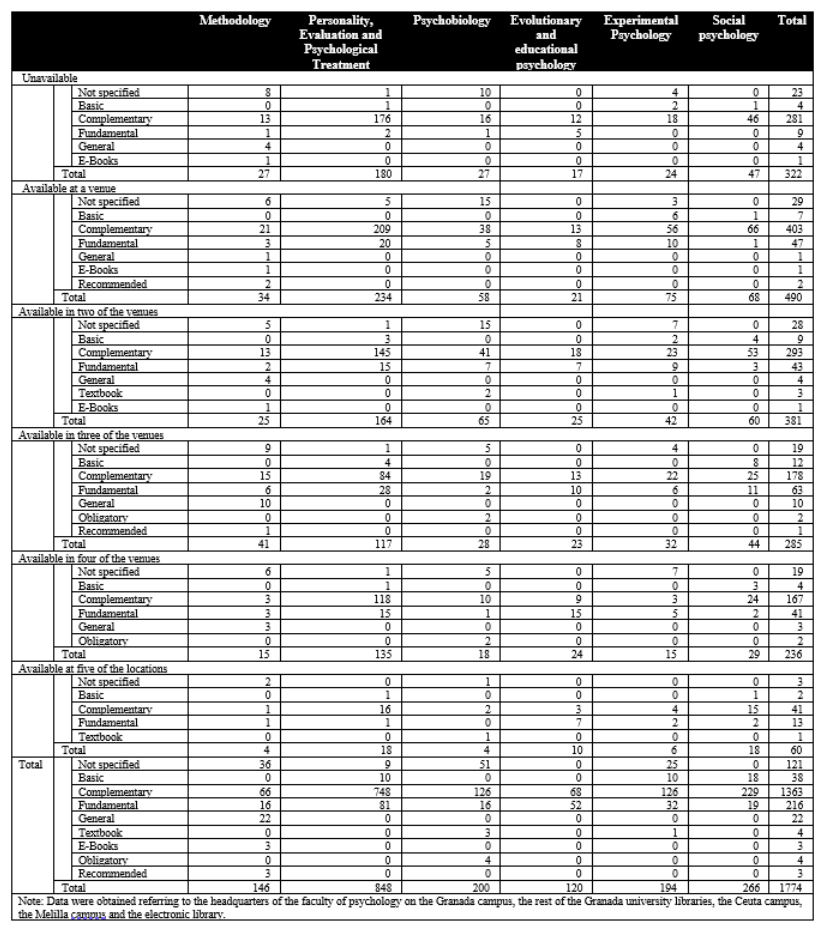

Table 1 Availability of the bibliography proposed by departments in the psychology degree of the Universidad de Granada

A summary of the type of document recommended by course and subject can be found in Table 2. Books accounted for $89.2 \%$ of the proposed bibliography. In the subject Psychosocial Risks and Occupational Health, 4th year, a journal was recommended. 
Psychology of Social Interaction and Groups (1st year), Psychological Assessment: Techniques and Applications, Fundamentals of Psychological Assessment (2nd year) and Memory and Representation (3rd year) were the subjects recommending the highest number of articles.

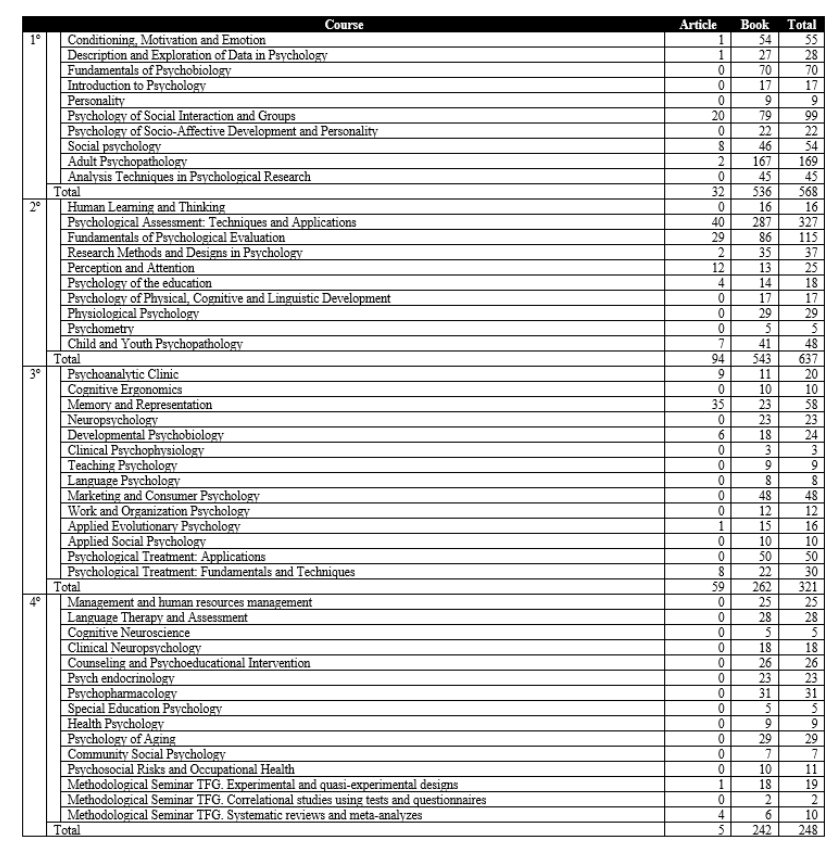

Table 2 Type of Bibliographies by Course and Subject in the Degree in Psychology at the Universidad de Granada

As for the average amount of bibliography per subject and credits, an average of 10.33 bibliographies was observed for subjects of 2 ECTS credits, and 37.89 for subjects of 6 ECTS credits.

Regarding the availability of bibliographies in the catalog, $34.2 \%$ of bibliographies were not available in the Faculty of Psychology and 870 references (49\%) were not available in any library of the rest of the faculties of the Granada Campus. $75 \%$ and $74.5 \%$ were not located at the Ceuta and Melilla campuses, respectively, and $78.4 \%$ were not available online. $18.2 \%$ of the total (322 references) were not available in any of the UGR libraries (of which 67 were scientific articles and 255 were books). Of the copies available in the Library of the Faculty of Psychology, all were lendable. In terms of updating the bibliography, it was observed that 1,341 documents $(75.59 \%)$ were up to date. In other words, there was no document available that was more up-to-date than the one recommended by the teacher. In this respect, $24.41 \%$ did have more up-to-date documents in the library catalog.

\section{Discussion}

Although the teaching methodology is changing and is being updated based on new technologies (Moreno-Guerrero et al., 2021), the bibliographies recommended by teachers are still a common point in pre and post COVID teaching. The present study aimed to carry out an analysis of the bibliographic background of the bibliographies that teachers recommend to students of the Psychology Degree at the UGR. This analysis provides relevant data not only in terms of the services provided by the university library but also in terms of teaching quality. In the present study, it was observed that only $12.5 \%$ of the bibliography proposed by the teachers was from the last five years. It is also important that, despite their age, documents published, for example, in 1923 are still relevant. Concerning the updating of these documents, $24.41 \%$ of the proposed bibliographies were found to have more recent documents in the library. Although the necessary competencies of the teacher include transmitting up-to-date and meaningful scientific knowledge (Álvarez-Rojo et al., 2011), it is interesting that bibliographies older than five years are still recommended. In this respect, it would be important to assess the specific training needs of psychology teachers (see Álvarez-Rojo et al., 2011) to determine the establishment of continuous training programs that favor teacher updating and specialization. On the other hand, it is possible to highlight how each teacher interprets the suitability of bibliographies, using terms such as Basic, Compulsory, Fundamental, General, Recommended, or Textbook. In this respect, while in one department 16 so-called fundamental bibliographies are recommended (Methodology), in another up to 81 are recommended (Personality, Assessment, and Psychological Treatment). In all cases, however, the lecturers extend these important bibliographies by proposing what they call Complementary Bibliography and, in the e-book proposals, there was no specification as to the category of these recommendations. In this respect, it could be difficult for students to discern what is a compulsory study or what is complementary training. This inconsistency in the naming of the labels could promote a certain distrust of the teaching guides among students, who perceive them as not very congruent. 
It would be interesting, in this respect, to promote not only the unification of these concepts or agreement among teachers when naming bibliographies, but also to promote teacher training in the competence of teaching planning, which includes the activity of selecting what is fundamental and important in the subject (Álvarez-Rojo et al., 2011). In this way, students' understanding of the importance of the material they are faced with could be facilitated. With regard to the analysis of credits per subject, there were no relevant differences. In this respect, it is worth noting that the number of bibliographies proposed by the teachers was, on average, three times higher in subjects with six ECTS credits than in those with two ECTS credits. There seems to be consistency in this criterion, although there were only three subjects with two ECTS credits. In terms of the availability of bibliographies, there was a notable percentage of documents not available at any of the sites. Of these, $14.41 \%$ were books. This data is important as it could suggest, on the one hand, that the library does not have a bibliography considered relevant by the teachers or, on the other hand, that the teachers do not provide the students with accessible and available bibliographies. In this respect, it would be interesting to promote initiatives not only to update the bibliographic collection but also the teaching guides, so that they are more coherent and adapted to the student.

Finally, of the bibliographies available at the Faculty of Psychology headquarters, all were loanable (i.e. none were reserved for exclusive use within the library). It would be interesting, in the future, to carry out circulation analyses of the available documents, so that the use of the documents proposed by the teachers in the guides could be known more directly.

\section{Conclusions}

In conclusion, analyzing the bibliographic resources of university libraries is an important task to obtain data on the updating and relevance of the bibliographies proposed by lecturers. In this way, strategies for improving the quality of teaching and services can be promoted.

The main limitation of this study is that it presents data from only one particular degree program. In this case, it is not possible to compare the data between different faculties at the national level or between different disciplines.
It would be interesting in the future to carry out analyses of bibliographic holdings (following the methodology presented in this paper) between faculties at different universities.

\section{References}

Álvarez-Rojo, V., Romero, S., Gil-Flores, J., Rodríguez-Santero, J., Clares, J., Asensio, I. ... Guardia, S. (2011). Necesidades de formación del profesorado universitario para la adaptación de su docencia al Espacio Europeo de Educación Superior (EEES). Relieve, 17, 1-22.

Buela-Casal, G., Guillén-Riquelme, A., DíazRomán, A., Carneiro-Barrera, A., \& QuevedoBlasco, R. R. (2019). Ranking 2019 de investigación de las universidades públicas españolas. Psicothema, 31, 351-362. doi:10.7334/psicothema2019.238

Carneiro-Barrera, A., Ruiz-Herrera, N. \& DíazRomán, A. (2019). Tesis doctorales en Psicología tras la adaptación al Espacio Europeo de Educación Superior. Revista de Investigación en Educación, 17, 32-43.

Domingo-Coscolla, M., Bosco, A., Carrasco Segovia, S \& Sánchez Valero, J. A. (2020) Fomentando la competencia digital docente en la universidad: Percepción de estudiantes y docentes. Revista de Investigación Educativa, 38, 167-782. doi:10.6018/rie.340551

Escudero, T. (2019). Evaluación del profesorado como camino directo hacia la mejora de la calidad educativa. Revista de Investigación Educativa, $\quad 37, \quad 15-37$. doi:10.6018/rie.37.1.342521

Fernández, C. M., Arbulo, M. M., Muñoz, J. P., Agudo, E. \& García, F. (2017). Análisis de la evaluación continua en el contexto del EEES. Revista Docencia e Investigación, 1, 81-100.

López López, M. C., León Guerrero, M. J. \& Pérez García, M. P. (2018). El enfoque por competencias en el contexto universitario español. La visión del profesorado. Revista de Investigación Educativa, 36, 529-545. doi:10.6018/rie.36.2.314351 
López Núñez, M. I., Rubio Valdehita, S. \& Díaz Ramiro, E. M. (2018). Rendimiento, contexto académico y salud percibida en estudiantes de psicología antes y después del EEES. REDU: Revista de Docencia Universitaria, 16, 1. 211226. doi:10.4995/redu.2018.8961

Mas-Torelló, Ó. \& Olmos-Rueda, P. (2016). El profesor universitario en el Espacio Europeo de Educación Superior: la autopercepción de sus competencias docentes actuales y orientaciones para su formación pedagógica. Revista Mexicana de Investigación Educativa, 21, 437470.

Moreno-Guerrero, A. J., Trujillo Torres, J. M., Romero Rodríguez, J. M., Hinojo Lucena, F. J., Aznar Díaz, I., Segura Robles, A., ... \& Tovar Gálvez, M. I. (2021). Proyecto de Innovación Docente:i Virtualízate! Adaptación de las metodologías y la evaluación a distintos escenarios educativos.

Núñez, M. I. L., Valdehita, S. R. \& Ramiro, E. M. D. (2018). Rendimiento, contexto académico y salud percibida en estudiantes de psicología antes y después del EEES. REDU: Revista de Docencia Universitaria, 16, 1.

Pérez Marfil, M. N. (2021). Memoria de proyectos de innovación y buenas prácticas docentes. Aprendizaje cooperativo aplicado a materias de másteres de ciencias de la salud. Valoración de conocimientos previos y prueba de evaluación a través del trabajo en grupo.

Piedra, Y. \& Ponjuán, G. (2021). Análisis de los patrones de colaboración del programa de formación doctoral en Bibliotecología y Documentación Científica. Revista Cubana de Información en Ciencias de la Salud, 32(1).

Quevedo-Blasco, R. \& Buela-Casal, G. (2019). Teacher Satisfaction in Spain with the European Higher Education Area: Arts and Humanities. Universitas Psychologica, 18, 1-16. doi:10.11144/Javeriana.upsy 18-5.tsse

REBIUN (1999). Normas y directrices para bibliotecas universitarias y científicas $\left(2^{a} \mathrm{ed}\right.$. aum.). Madrid: Ministerio de Educación y Cultura.

Reitz, J. (2004). Dictionary for Library and Information Science. Westport, Connecticut: Libraries Unlimited.
Salajan, F. D. (2018). An analysis of rhetorical devices in policy narratives on the European Institute of Innovation and Technology: Implications for European higher education. European Educational Research Journal, 17, 555-583. doi:10.1177/1474904117720793

Shanghai Ranking Consultancy (2019). Academic Ranking of World Universities 2019 [ARWU 2019]. Recuperado de: http://www.shanghairanking.com/arwu2019.ht $\mathrm{ml}$

Saravia Gallardo, M. A. (2008). Calidad del profesorado: un modelo de competencias académicas. Revista de Investigación Educativa, 26, 141-156.

Universidad de Granada (2020). La Universidad de Granada en cifras. Recuperado de: https://www.ugr.es/destacado/la-universidadde-granada-en-cifras 